УДК 65.01

JEL D01

DOI 10.31375/2226-1915-2020-4-108-119

\section{МОТИВАЦІЯ \\ ПЈПРИЕМНИЦЬКОЇ ДІЯЛЬНОСТІ В КОНТЕКСТІ ПРОБЛЕМНОГО ПІДХОДУ}

\section{P.I. Завадяк}

к.е.н., доцент кафедри економіки і підприємництва roman.zavadyak@uzhnu.edu.ua ORCID 0000-0002-2202-6282

$$
\text { I.I. Качур }
$$

студент магістерської програми кафедри економіки і підприємництва К.В. Попович

студент магістерської програми кафедри економіки і підприємництва

ДВНЗ «Ужгородський національний університет», Ужсгород, Україна

Анотація. Метою даної роботи є дослідження сутності підприємницької діяльності та сучасних мотивачійних кониептів, що дозволяс виявити та систематизувати основні проблеми мотивачії підприємничтва.

Дослідження показало, шо мотивачія підприємницької активності - комплексне явище, яке зачіпає як внутрішній потенціал бізнесу, так й різноманітних контрагентів та оточення бізнесу в иілому. Побудовано трикутник мотиваиї, ио містить самомотивацію ділового актора; мотивацію персоналу та мотивацію третіх осіб, що контактують з бізнесом прямо або опосередковано.

У прочесі дослідження виявлено, щуо існує широкий спектр проблем мотивації підприємницької діяльності, серед яких визначальними виділено. група проблем, щчо охоплюють дослідження та активізацію мотивів створення власного бізнесу, початку господарських дій; група проблем, яка стосується визначення сутності мотивачії підприємнииької діяльності та полягає у діагностииі потреб, на яких засновується сучасна концепція мотивачїі; проблеми мотивації підприємницької діяльності, щуо знаходяться в соціально-культурному оточенні, яке може стимулювати до початку бізнесу або гальмувати ініціативу; проблеми наявності та виникнення протиріч в прочесі ділової активності, які мають перспективу перетворитися в конфлікт інтересів різноманітних учасників економічного прочесу. Представлена класифікачія проблем за ознаками: в залежності від місия виникнення, часу виникнення, від способу вирішення та складності.

Ключові слова: підприсмництво, моти вація, проблема, класифікація проблем, мотив, потреба, конфлікт.

(C) Завадяк P.I., Качур I.I., Попович К.В., 2020

\section{8}

УДК 65.01

JEL D01

DOI 10.31375/2226-1915-2020-4-108-119

МОТИВАЦИЯ

ПРЕДПРИНИМАТЕЛЬСКОЙ ДЕЯТЕЛЬНОСТИ

В КОНТЕКСТЕ ПРОБЛЕМНОГО ПОДХОДА

Р.И. Завадяк

к.э.н., доцент кафедры

экономики и предпринимательства roman.zavadyak@uzhnu.edu.ua И.И. Качур

студент магистерской программы кафедры экономки и предпринимательства К.В. Попович

студент магистерской программы кафедры экономки и предпринимательства

Ужгородский национальный университет, Ужгород, Украина

Аннотация. Целью статьи является исследование сущности предпринимательской деятельности и современных мотивационных концептов, что позволяет выявить и систематизировать основные проблемы мотивации предпринимательства.

Исследование показало, что мотивация предпринимательской активности - комплексное явление, затрагивающее как внутренний потенциал бизнеса, так и разнообразных контрагентов, окружение бизнеса в иелом.

Представлен треугольник мотивации, содержащий краеугольные элементы: самомотиваичю делового актора, оказание влияния на персонал персонала и стимулирование третьих лиц, контактирующих с бизнесом прямо или косвенно.

В прочессе исследования обнаружено, что существует иирокий спектр проблем мотиваиии предпринимательской деятельности, среди которых определяющими выделены: группа проблем, охватываюших исследования и активизаиию мотивов создания собственного бизнеса; круг задач, определяюших сущности потребностей, на которых основывается современная концепция мотива иия; проблемы, что находятся в сочиально-культурном окружении и могут стимулировать начало бизнеса или тормозить инициативу; ситуации с наличием или возникновением противоречий в проиессе деловой активности, которые имеют перспективу превратиться в конфликт интересов разнообразных участников экономического прочесса.

Представлена классификация проблем: в зависимости от места возникновения, времени возникновения, способа решения, сложности.

Ключевые слова: предпринимательство, мотивация, проблема, классификация проблем, мотив, потребность, конфликт. 
DOI 10.31375/2226-1915-2020-4-108-119

\title{
MOTIVATION OF ENTREPRENEURIAL ACTIVITY \\ IN THE CONTEXT OF THE PROBLEM APPROACH
}

\author{
Roman Zavadyak \\ Ph.D., Associate Professor of the Department of Economics and Entrepreneurship \\ roman.zavadyak@uzhnu.edu.ua \\ ORCID 0000-0002-2202-6282 \\ Ivan Kachur \\ Student of the master's program at the Department of Economics and Entrepreneurship \\ Kristian Popovych \\ student of the master's program at the Department of Economics and Entrepreneurship
}

\section{Uzhgorod National University, Uzhgorod, Ukraine}

\begin{abstract}
The aim is to study the essence of entrepreneurial activity and modern motivational concepts, which allows you to identify and systematize the main problems of motiva-ting business activity.

The study showed that the motivation of entrepreneurial activity is a complex phenomenon that affects both the internal potential of the business and various counterparties and the business environment as a whole. The main elements of motivation of entrepreneurial activity are: self-motivation of a business actor (any activity will not be effective without internal motivation), staff motivation (entrepreneurship is the result of attracting various resources, including labor, which should be stimulated to achieve goals of the organization) and motivation of third parties who contact the business directly or indirectly.

The constructed triangle of motivation provides opportunities in the course of practical activity of business to allocate the basic directions of diagnostics of problems of motivation of business activity.

The study showed that there is a wide range of problems of business motivation, among which the determinants are: the first group of problems, covering research and activation of motives for starting your own business, starting a business; the second group of problems concerns the definition of the essence of business motivation, is to diagnose the needs on which the modern concept of motivation is based; problems of motivation of entrepreneurial activity are also in the socio-cultural environment, which can stimulate the start of business or inhibit initiative; problems of existence and emergence of contradictions in the process of business activity, which have the prospect of becoming a conflict of interest of various participants in the economic pro-cess. It is proposed to systematize the problems of motivation of entrepreneurial activity on the basis of classification according to the following features: depending on the place of origin, the time of origin, the method of solution, the complexity.
\end{abstract}

Keywords: entrepreneurship, motivation, problem, classification of problems, motive, need, conflict. 
Постановка проблеми. Підприємницька діяльність - це феномен, що відіграє велику кількість ролей: являс собою сенс соціально-економічної активності ділових акторів, виступає механізмом формування інноваційного середовища; створює нову якість життя населення країни та регіону. Неповний вказаний перелік функцій підприємництва охоплює не лише економічну сферу життєдіяльності, але й зачіпає соціальну площину, культуру, мораль, різноманітні інститути тощо. Підприємництво створює не лише продукт чи послугу, а й забезпечує перманентну трансформацію суспільства в цілому та окремих його елементів та учасників. Все це визначає проблемний контент підприємництва апріорі, дозволяє подивитися на підприємницьку активність як конгломерат не лише взаємопов'язаних сфер суспільства, але й як на гроно протиріч, що окутують бізнес й викликають суперечки розвитку.

Доповнює коло проблем мотивація підприємницької діяльності, яка додає психологічні, культурні, організаційні та управлінські імпульси розвитку бізнесу, що також несе в собі згусток проблем та протиріч. Ще минулого століття питання мотивації підприємництва опанували думками економістів. Так, Куратко Д. (D.F. Kuratko, J.S. Hornsby, D.W. Naffziger, 1997) та його колеги стверджували, що, щоб описати та визначити підприємницький процес, потрібно зрозуміти мотивацію майбутніх бізнесменів створювати та підтримувати свої підприємства [5].

Все це обумовлює доцільність дослідження мотивації підприємниць- кої діяльності $з$ позиції діагностики проблем, вирішення яких підвищує ефективність та конкуренто-спроможність бізнесу.

Огляд останніх досліджень та публікацій. Кім Сунг та його співавтори (Ng Kim-Soon, Abdul Rahman Ahmad and Nurul Nadia Ibrahim, 2018) досліджують фактори мотивації початку підприємницької активності та стверджують наступне: «Факторами підприємницької мотивації, що впливають на кар'єрний намір бути підприємцем, $\epsilon$ соціальні норми, що включають індивідуальне сприйняття важливості того, як інші оцінюють та підтримують створення нового бізнесу), суб'єктивні норми (індивідуальне уявлення про свої здібності та толерантність до виконання підприємницьких завдань), а також ставлення до поведінки (індивідуальне усвідомлення важливості та цінності підприємництва) підприємницької мотивації» [7]. Взаємодія між намірами та мотивацією підприємницької діяльності описана Єделман Л., Брам С., Манолова Т., Грин П. (Edelman L.F., Brush C.G., Manolova T.S., Greene P.G., 2010), які довели, що «стимул мотивації може трансформувати прихований намір стимулювати підприємництво» [2]. Словацькі дослідники Дубравіська М. та ін. (Dubravská M., Mura L., Kotulič R., Novotny J., 2015) аналізують мотивацію підприємців виходити на міжнародні ринки [1]. Кубіній Н.Ю. розкриває історичний шлях мотивації, показує роль інноваційних методів мотивації у досягненні стратегічних цілей на прикладі досягнень Македонського А. [13]. Мотивація в малому бізнесі описана в 
DEVELOPMENT OF MANAGEMENT

AND ENTREPRENEURSHIP METHODS ON TRANSPORT, № 4 (73), 2020
РОЗВИТОК МЕТОДІВ

УПРАВЛІННЯ ТА ГОСПОДАРЮВАННЯ

НА ТРАНСПОРТІ, № 4 (73), 2020 монографії закарпатських дослідників [15], які вважають дану функцію менеджменту визначальною для створення підприємницької структури. Проблеми мотивації визначені в дослідженнях ролі підприємництва в процесі регіонального розвитку [3; 4].

Разом 3 тим, знаходиться поза увагою дослідження різних напрямків здійснення функції мотивації в процесі підприємницької діяльності та виникнення проблем в процесі здійснення економічної діяльності.

Метою даної роботи $є$ дослідження сутності підприємницької діяльності та сучасних мотиваційних концептів, що дозволяє виявити та систематизувати основні проблеми мотивації підприємництва.

Для досягнення мети вирішені завдання:

- окреслені специфічні риси підприємництва як феномену сучасного економічного життя;

- побудовано трикутник мотивації підприємницької активності;

- визначені основні проблеми мотивації в процесі ділових починань.

Методологісю дослідження $\epsilon$ застосування наукової абстракції в процесі діагностики основних проблем бізнес-антрепренерства; прийоми дедукції, що дозволили розчленити мотивацію на три складові частини; узагальнення як методу встановлення групи основних проблем мотивації підприємницької діяльності та ін.

Основний матеріал дослідження. Проблемний підхід - це дослідження сутності явища в контексті протиріч та викликів, що містить його екзистенція та перспективи розвитку. Мотивація підприємницької діяльності охоплює комплекс питань, які включають економічну, управлінську, психологічну складові впливу на персонал та на підприємця в процесі його самомотивації.

Підприємницька діяльність багатогранна, що обумовило широкий спектр підходів до іiі визначення. Загальноприйнятим $€$ визначення підприємництва як діяльності, спрямованої на створення вартості. Більш вузькі визначення описують підприємництво як процес проектування, запуску та ведення нового бізнесу, який часто спочатку є малим бізнесом, але здатним до розвитку. Крім цього, підприємництво визначається як «не будь-яка господарська діяльність, а особливий вид діяльності... і ця особливість характеризується такими ознаками:

- це самостійна діяльність, діяльність «за свій рахунок», так як основою підприємницької діяльності є власність підприємця;

- це ініціативна творча діяльність, в основі здійснення якої лежить власна ініціатива, творчо-пошуковий, інноваційний підхід;

- це систематична діяльність, яка $є$ постійною, пов'язаною з відтворювальним процесом i обов'язково офіційно зареєстрованою;

- це діяльність, яка здійснюється на власний ризик, під власну економічну (майнову) відповідальність;

- це діяльність, метою якої $\epsilon$ одержання прибутку або власного доходу» [11].

Підприємницька діяльність згідно до Господарського кодексу України відбувається у сфері соціальноекономічних відносин і визначається наступним чином: «Господарська ді- 
яльність, що здійснюється для досягнення економічних і соціальних результатів та 3 метою одержання прибутку, є підприємництвом» [10].

Для початку підприємницької діяльності та успішного функціонування бізнесу, досягнення його мети потрібна мотивація. Відмінною рисою мотивації підприємницької діяльності $€$ iii комплексний характер. Так, мотивація поділяється на само- мотивацію та мотивацію інших осіб. У процесі підприємницької діяльності виникає трикутник мотивації, який включає три іiі види, коли мотивація інших осіб поділяється на мотивацію персоналу та мотивацію осіб, що знаходяться поза межами бізнесу (постачальники, покупці, банкіри тощо, яких в бізнесі називають контрагентами (рис.1):

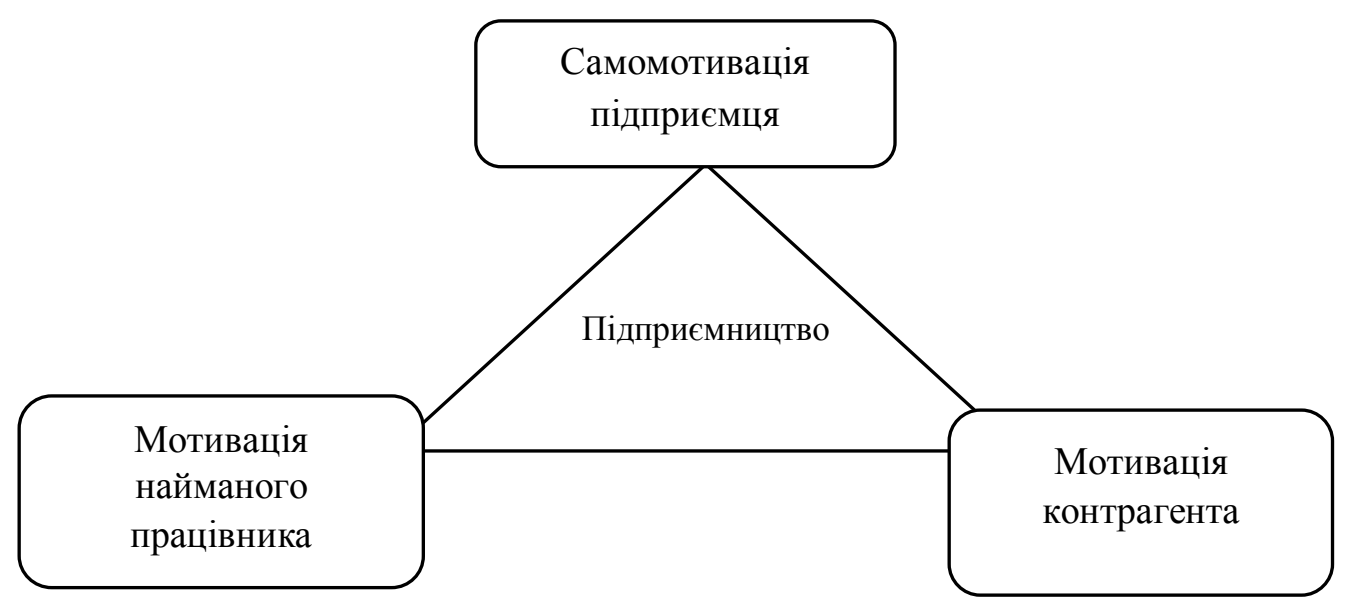

Рис. 1. Трикутник мотивації, притаманний підприємницттву

Джерело: складено Завадяком Р.I.

Мотивація - це внутрішній процес. Незалежно від того, визначаємо ми це як потяг чи потребу, мотивація - це умова всередині нас, яка бажає змін, як у собі, так i в оточенні. Коли ми використовуємо цю криницю енергії, мотивація наділяє людину спонуканням та напрямком, необхідним для взаємодії 3 навколишнім середовищем адаптивним, відкритим, тим що вирішує проблеми. Суть мотивації полягає в напруженій і стійкій цілеспрямованій поведінці.
Таким чином, перша проблема, яка виникає при дослідженні мотивації підприємницької діяльності - це необхідність виявлення мотивів створити власний бізнес.

Дослідження мотивації в психології обертається навколо надання найкращих можливих відповідей на два фундаментальних питання: що спричиняє поведінку та чому поведінка змінюється за своєю інтенсивністю?

Мотиваційна наука - це поведінкова галузь, яка прагне побудувати теорії про те, що становить моти- 
DEVELOPMENT OF MANAGEMENT

AND ENTREPRENEURSHIP METHODS ON TRANSPORT, № 4 (73), 2020
РОЗВИТОК МЕТОДІВ

УПРАВЛІННЯ ТА ГОСПОДАРЮВАННЯ

НА ТРАНСПОРТІ, № 4 (73), 2020 вацію людини і як працюють мотиваційні процеси. Виявлення, «як мотивація може вплинути на підприємницький процес на кожному 3 його етапів», за думкою Шейна $C$. та його однодумців (Shane, S., Locke, E.A. \& Collins, C.J., 2012) доцільно узгоджувати 3 «пізнанням, можливостями та екологічними силами» [8].

Мотиви - це внутрішні переживання у формі потреб, пізнань та емоцій, які є прямими та основними причинами мотивованих дій. Соціальний контекст та зовнішні події виступають попередниками мотивів, що викликають або не викликають мотиваційні стани. У даному випадку мотивація підприємницької діяльності сукупність мотивів досягти певного економічного, соціального та культурного результату.

Друга проблема визначення сутності мотивації підприємницької діяльності названа в даному дослідженні ієрархічною і полягає у діагностиці потреб, на яких засновується сучасна концепція мотивації. Одним 3 перших дослідників потреб є Маслову A. (Maslow, А.Н. (1970). [6] Науковий спадок вказаного вченого дозволяє виділяти п'ять рівнів потреб:

- фізіологічні - стосуються потреб у їі, воді, житлі тощо, які $є$ найбільш базовими для людини;

- безпека (таки, що описують прагнення людини до захисту);

- приналежність, причетність та любов: основна увага приділяється соціальним аспектам робочих та неробочих ситуацій;

- повага та влада - цей рівень ієрархії стосується проблем, які людина може викликати щодо майстерності, компетентності та статусу. Лю- ди, які виявляють потреби в повазі, можуть також бажати визнання своїх досягнень, і вони можуть бажати матеріальних символів успіху, таких як великий офіс, назва посади керівника, визнання громадськості, інші привілеї та винагороди пов'язані з успіхом, як членство в клубі або розкішний автомобіль;

- самоактуалізація, саморозвиток. Цей вид потреб відображає бажання особистості рости та розвиватися на повну силу; до нього включена можливість проявити творчість у роботі, а також бажання автономії, відповідальності та викликів.

Мотивація в процесі підприємницької діяльності, коли вона походить із внутрішніх мотивів, класифікованих за потребами, пізнаннями та емоціями, часто сприймається як більш безпосередня та потужна, ніж зовнішня мотивація.

Проблема мотивації підприємницької діяльності також полягає в соціально-культурному оточенні, яке може стимулювати до початку бізнесу або гальмувати ініціативу. Оскільки ми не існуємо у вакуумі, внутрішні переживання не можуть мати місце без певного ступеня зовнішнього впливу, будь то у формі наслідків, стимулів чи інших форм тиску, що виникають із соціального контексту та культури нашого середовища. Прикладом мотивації регіонального середовища можливо назвати Кремнієву долину, в якій сформовано культуру підприємництва та інноваційного аншлагу. Так, статистика інформаційної економіки Каліфорнії свідчить, що «в зоні затоки СанФранциско працюють понад 386000 спеціалістів IT-галузі, що дає право 
DEVELOPMENT OF MANAGEMENT

AND ENTREPRENEURSHIP METHODS ON TRANSPORT, № 4 (73), 2020
РОЗВИТОК МЕТОДІВ

УПРАВЛІННЯ ТА ГОСПОДАРЮВАННЯ

НА ТРАНСПОРТІ, № 4 (73), 2020
Кремнієвій долині вважатися найбільшим технологічним центром в США. На кожну 1000 зайнятих припадає 286 працівників IT-сфери» [12]. Коли зовнішні умови та внутрішні мотиви узгоджуються, вони створюють стигле середовище для залучення в бізнес.

Місцевий соціум продукує певну соціальну поведінку потенційного або функціонуючого підприємця. При цьому доцільно враховувати, що «мотивація соціальної поведінки також може бути представлена на основі певної типології. До основних мотивів соціальної поведінки можна віднести наступні:

$\checkmark$ мотив досягнення людини (він реалізується в активних прагненнях до високих результатів своєї діяльності, професійної успішності, високого життєвого комфорту, духовного вдосконалення, переваг над іншими тощо). Його розвитку сприяє здатність особистості пов'язувати досягнуті результати 3 цілеспрямованими діями і затраченими зусиллями, інтелектуальний рівень;

$\checkmark$ мотив аффіліації (розкривається на рівні встановлення, підтримки, збереження гарних людських стосунків 3 іншими, в першу чергу 3 референтної групи, усвідомлення їх цінності);

$\checkmark$ мотив влади (формується, як правило, на основі комплексів неповноцінності чи завищеної самооцінки людини. Реалізується в різних видах поведінки, спрямованої на контроль над іншими людьми, їх залякування, примус, маніпулювання їхньою свідомістю, шантаж)» [9].

Наступною проблемою мотивації підприємницької діяльності мож- ливо назвати конфлікт, якій виявляе протиріччя в різних сферах ділового життя i може слугувати як стимулюючим фактором, так й демотиватором.

Конфлікт як зіткнення інтересів - це невід'ємна частина підприємництва, коли антагонізм інтересів виникає між:

а) конкурентами, в цьому випадку мотивує до дій, що забезпечують формування переваг в економічному змаганні суб'єктів бізнесу;

б) потенціалом та стратегічними цілями. Недостатній потенціал або неадекватні довгострокові наміри можуть призвести до бізнес-фіаско або сприяють пошуку додаткових ресурсів, необхідних для реалізації стратегічних намірів;

в) керівництвом та найманими працівниками, що сприяє пошуку нових організаційних фреймінгів;

г) бізнесом та соціумом, коли діяльність підприємства не вписується в очікування мешканців, влади або інших соціальних гравців. У цьому випадку бізнес буде мотивованим до диверсифікації дій, спрямованих на саморекламу, і повинен шукати сфери, в яких інтереси різних суб'єктів співпадатимуть і бути активним в паблік рілейшнз.

Важливим інструментом переведення конфлікту 3 демотиватора в мотиватор є довіра, яка несе в собі не лише психологічне, але й економічне навантаження, що відмічене Алтман Й. та його співавтором [14].

Таким чином, запропоновані вище ідеї дозволяють класифікувати проблеми, що виникають у площині предмета даного дослідження, наступним чином (рис. 2): 


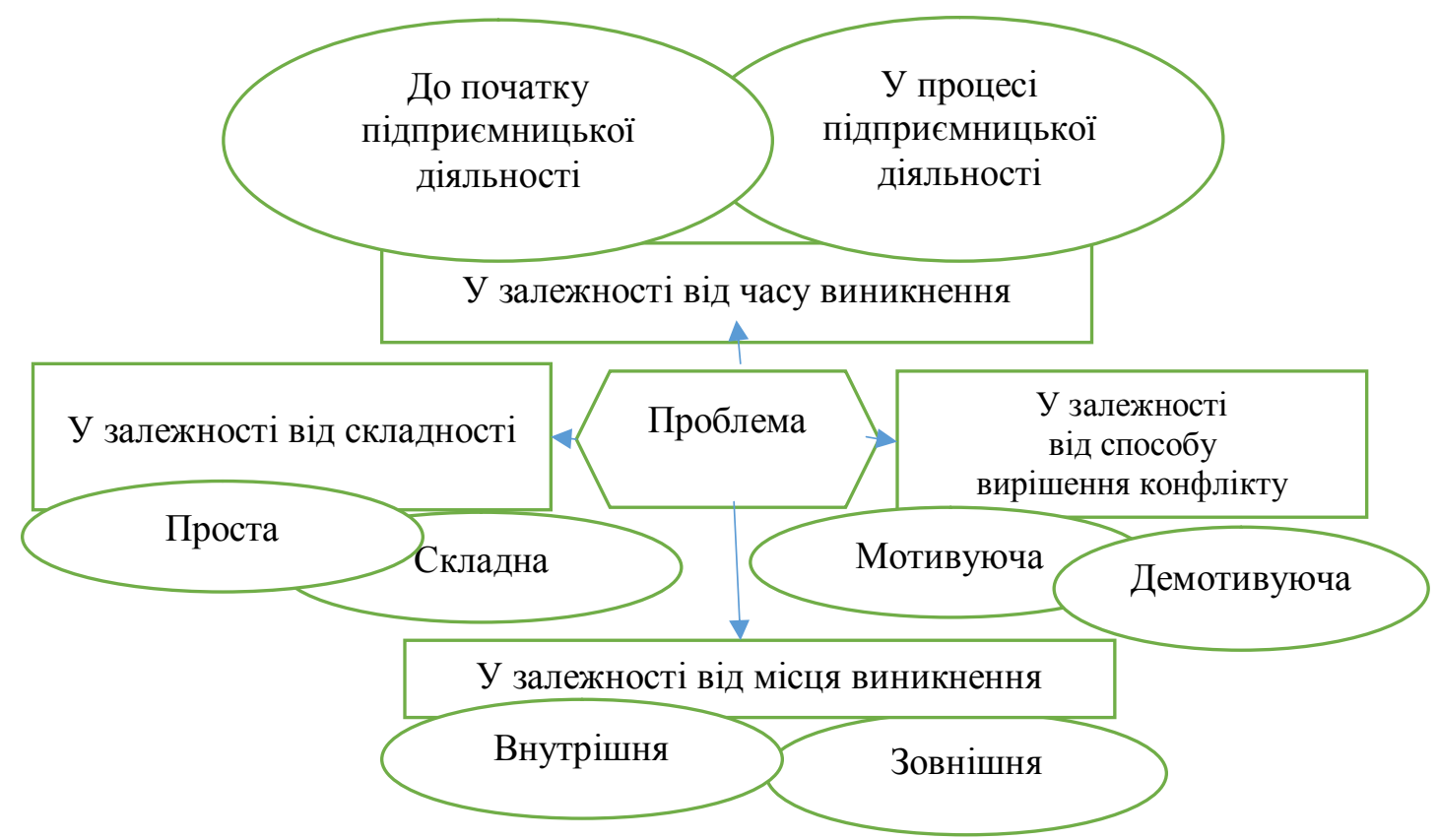

Рис. 2. Види проблем мотивації підприємницької діяльності

\section{Джерело: складено авторами}

Кожна проблема індивідуальна за змістом, причинами, місцем виникнення наслідками тощо, вимагає iі діагностики в конкретному випадку, що слугує підвищенню якості підприємницької активності через вдосконалення мотивації останньої.

Висновки. Дослідження показало, що мотивація підприємницької активності - комплексне явище, яке зачіпає як внутрішній потенціал бізнесу, так й різноманітних контрагентів та оточення бізнесу в цілому.

Показано, що основними елементами мотивації підприємницької діяльності є: самомотивація ділового актора (будь-яка діяльність не буде результативною без внутрішнього спонукання людини), мотивація пер- соналу (підприємництво - це результат залучення різноманітних ресурсів, в тому числі й трудових, які повинні бути стимульовані до досягнення мети організації) та мотивація третіх осіб, що контактують 3 бізнесом прямо або опосередковано.

Побудований трикутник мотивації надає можливості в процесі практичної діяльності бізнесу виділити основні напрямки діагностики проблем мотивації підприємницької діяльності.

Дослідження показало, що існує широкий спектр проблем мотивації підприємницької діяльності, серед яких визначальними виділено:

- перша група проблем, що охоплюють дослідження та активі- 
зацію мотивів створення власного бізнесу, початку господарських дій;

- друга група проблем стосується визначення сутності мотивації підприємницької діяльності, полягає у діагностиці потреб, на яких засновується сучасна концепція мотиваціï;

- проблеми мотивації підприємницької діяльності також знаходяться в соціально-культурному оточенні, яке може стимулювати до початку бізнесу або гальмувати ініціативу;

- проблеми наявності та виникнення протиріч в процесі ділової активності, які мають перспективу перетворитися в конфлікт інтересів різно- манітних учасників економічного процесу.

Запропоновано систематизувати проблеми мотивації підприємницької діяльності на основі класифікації за наступними ознаками: у залежності від місця виникнення, часу виникнення, способу вирішення та від складності.

У подальшому дослідженні заплановано побудувати модель мотивації підприємницької діяльності, яка дозволить економічному актору визначати вузлові проблеми та знаходити шляхи вирішення.

\section{СПИСОК ЛІТЕРАТУРИ}

1. Dubravská M., L. Mura L., R. Kotulič R., J. Novotny J. Internationalization of Entrepreneurship - Motivating Factors: Case Study of the Slovak Republic. Acta Polytechnica Hungarica / 2015. Vol. 12, No. 5. URL: http://acta.uniobuda.hu//Dubravska Mura Kotulic Novotny 61.pdf

2. Edelman LF, Brush CG, Manolova TS, Greene PG (2010). Start-up motivations and growth intentions of minority nascent entrepreneurs. Journal of Small Business Management. 2010. 48(2), 174-196.

3. Kubiniy N., Marhitich V., Kosovilka T.(2019) Potential of strategic development of regional economy. Challenges of Globalization in Economics and Business (The 4th International Scientific Conference. Georgia, Tbilisi, November 1-2, 2019 Proceedings). Tbilisi: Ivane Javakhishvili Tbilisi State University, 237-242. URL: www.tsu.ge/data/file_db/economist_faculty/konf\% 20IV.pdf

4. Kubiniy N., Marhitich V., Kosovilka T.(2020) Modern Content of Strategic Regional Development Potential. Economics and Business.2020. № 1 . URL: http://eb.tsu.ge/?cat=nomer\&leng=eng\&adgi=945\&title=Modern $\% 20$ Content $\% 200 \% \% 20$ Strategic\%20Regional\%20Development $\% 20$ Potential

5. Kuratko D., Hornsby J., Naffziger D. (1997). An examination of owner's goals in sustaining entrepreneurship. Journal of Small Business Management, 35, 24-33.

6. Maslow, A.H. (1970). Motivation and personality. New York: Harper \& Row. $369 p$. 
7. Ng Kim-Soon, Abdul Rahman Ahmad and Nurul Nadia Ibrahim (2018). Understanding the Motivation that Shapes Entrepreneurship Career Intention, IntechOpen. Available from: https://www.intechopen.com/books/ entrepreneurship-development-tendencies-and-empirical-approach/understanding-themotivation-that-shapes-entrepreneurship-career-intention

8. Shane, S., Locke, E. A., Collins, C. J. (2012). Entrepreneurial motivation. 13(2). Retrieved [insert date], from Cornell University, ILR School site: http://digitalcommons.ilr.cornell.edu/articles/830

9. Алексеенко Т. (2016). Мотивачія, механізми і вікові передумови соиіальної поведінки особистості в групі. Wschodnioeuropejskie Czasopismo Naukowe. URL: http://lib.iitta.gov.ua/708773/1/EESA_p4_10-13.pdf

10. Господарський кодекс України. URL: https://zakon.rada.gov.ua/laws/show/ 436-15\#Text

11. Грушко В.І., Наконечна О.С., Чумаченко О.Г. (2017) Національні фінанси. Підручник. К. : ВНЗ «Університет економіки та права «КРОК», 660 с.

12. Кремниевая долина. URL: https://ru.wikipedia.org/wiki/\%D0\%9A\%D1\% 80\% $D 0 \% B 5 \% D 0 \% B C \% D 0 \% B D \% D 0 \% B 8 \% D 0 \% B 5 \% D 0 \% B 2 \% D 0 \% B 0 \% D 1 \% 8 F$ $\% D 0 \% B 4 \% D 0 \% B E \% D 0 \% B B \% D 0 \% B 8 \% D 0 \% B D \% D 0 \% B 0$

13. Кубиний Н.Ю., Пулянович Е.В., Косовилка Т.И. (2017). Институализачия инновачионных стратегий: ретроспективный бекграунд. Науковий вісник Ужсгородського університету. Серія: Економіка. Вип. 2. C. 83-86. URL: http://nbuv.gov.ua/UJRN/Nvuuec_2017_2_12

14. Кубиний Н., Алтман Й. Виды доверия и их оценка // Науковий вісник Ужсгородського університету. Серія Економіка, випуск 2. Збірник наукових прачь. Ужгород, 2016. С.148-152.

15. Мікловда В., Ступко А., Брітченко I, Кубіній Н. (2012). Малий бізнес як фактор розвитку конкурентоспроможності регіону. Полтава: TOВ «Фірма «Техсервіс», 200 c.

\section{REFERENCES}

1. Vuchic, V. (1999). Transportation for Livable Cities, Center for UrbanPolicy Research, New Brunswick.

2. Gagatsi, E., Giannopoulos, G., Aifantopoulou, G., Charalampous, G. (2016). Stakeholders-based multi-criteria policy analysis in maritime transport: from theory to practice, Greece

3. Noran, O.S. (2000). Business modelling: Uml vs. idef.

4. Matviienko, M. (2018). Business structures at a maritime enterprise. Development of management and entrepreneurship methods on transport, 14-25. DOI: 10.31375/2226-1915-2018-4-14-25.

5. Nyenno, Iryna, Nitsenko, Vitalii (2017). Business model for a sea commercial port as a way to reach sustainable development goals, Journal of Security and Sustainability Issues. 
6. Osterwalder, A and Pigneur (2010). Business Model Generation, John Wiley \& Sons Inc.,p. 281, Hoboken, New Jersey.

7. Amit, $R$ and Zott, C. (2012). Creating Value Through Business Model Innovation. Sloan Management Review, Vol. 53, No. 3, pp. 41-49.

8. Bowman, C. and Ambrosini, V. (2000). Value Creation Versus Value Capture: Towardsa Coherent Definition of Value in Strategy. British Journal of Management, Vol. 11, No. 1, pp. 1-15.

9. Bereznoy, A. (2014). Innovative business-model in competitive strategy of the big company, Issues of Economy, 9, 65-81.

10. Schweizer, L. (2005). Concept and evolution of business models, Journal of General Management, 31(2), 37-56.

11. Alderton, P. (2008). Port Management and Operations. London: Published by Informa.

12. Stevens, H. (2007). The institutional position of seaports: an international comparison. Springer Science \& Business Media. T. 51. P. 8-16.

13. Robinson, $R$. Ports as elements in value-driven chain systems: the new paradigm. Maritime Policy \& Management. 2002. Vol. 29. № 3. P. 241-255. DOI: $10.1080 / 03088830210132623$

14. Author, Koen, Frenken, Juliet (2017). Putting the sharing economy into perspective. https://doi.org/10.1016/j.eist.2017.01.003.

15. Williamson, https://www.sciencedirect.com/ science/article/pii/ S22104 22417 300114 - bbib 0215O. (1981). The economics of organization: the transaction cost approach. Am. J. Sociol., 87 (1981), pp. 548-577 CrossRefView Record in ScopusGoogle Scholar.

Стаття надійшла до редакиії 22.09.2020

Посилання на статтю: Завадяк P.I., Качур I.I., Попович К.В. Мотивація підприємницької діяльності в контексті проблемного // Розвиток методів управління та господарювання на транспорті: Зб. наук. праць, 2020. № 4 (73). C. 108-118. DOI 10.31375/2226-1915-2020-4-108-118.

Article received 22.09.2020

Reference a JournalArtic: Zavadyak Roman, Kachur Ivan, Popovych, Kristian. Motivation of entrepreneurial activity in the context of the problem approach // Development of management and entrepreneurship methods on transport. 3, 108-118. DOI 10.31375/2226-19152020-108-118. 